\title{
MEKANISME OPERASIONALISASI SAHAM SYARI'AH DI INDONESIA DAN NEGARA LAIN
}

\author{
Oleh: \\ Azka Amalia Jihad \\ Konsentrasi Keuangan Perbankan Syari'ah, Prodi Hukum Islam, \\ Program Pascasarjana UIN Sunan Kalijaga Yogyakarta \\ Azaji Jihad@yahoo.com \\ Ar Royyan Ramly \\ Dosen Fakultas Syariah Universitas Serambi Mekkah Banda Aceh \\ royleesama@gmail.com
}

\begin{abstract}
Islamic stocks is one of the instruments in islamic capital market which is operated based on islamic principles. Islamic stocks are the securities proof of equity participations in the company and with the evidence of these investments, the shareholders are entitled to receive part of the profits. Operational mechanisms of islamic stocks is differently in each country. There are some problems of the mechanisms on screening process. Assessment criteria of islamic stocks broadly divided into qualitative and quantitative criteria. Qualitative criteria are based on halal and haram, while quantitative criteria are based on the financial performance of the company. There is a differences of shari'a criteria in each country, specially at JII, DJIM, and KLSI. The differences will impact to growth and development of islamic stocks in each country.
\end{abstract}

Keywords:saham syari'ah, operasionalisasisaham syari'ah, screening

\section{A. Pendahuluan}

Saham merupakan surat berharga yang sudah banyak dikenal oleh masyarakat. Saham adalah surat berharga keuangan yang diterbitkan oleh suatu perusahaan saham patungan sebagai suatu alat untuk meningkatkan modal jangka panjang(Manan, 2012). Sedangkan pengertian saham syari'ah menurut OJK adalah surat berharga bukti penyertaan modal kepada perusahaan dan dengan bukti penyertaan tersebut pemegang saham berhak untuk mendapatkan bagian hasil dari usaha perusahaan tersebut. Konsep penyertaan modal dengan hak bagian hasil usaha ini merupakan konsep yang tidak bertentangan dengan prinsip syariah. Prinsip syariah mengenal konsep ini sebagai kegiatan musyarakah atau syirkah. 
Berdasarkan analogi tersebut, maka secara konsep saham merupakan efek yang tidak bertentangan dengan prinsip syariah. Namun demikian, tidak semua saham yang diterbitkan oleh emiten dan perusahaan publik dapat disebut sebagai saham syariah.Pada paper ini akan dibahas secara khusus mengenai mekanisme dan operasionalisasi saham syari'ah di Indonesia dan negara-negara lain, serta perkembangannya.

\section{B. Saham Syari'ah}

Saham dalam bahasa Belanda disebut dengan "aandeel", dalam bahasa Inggris disebut dengan "share", dalam bahasa Jerman disebut dengan "aktie", dan dalam bahasa Perancis disebut dengan "action". Semua istilah tersebut mempunyai arti surat berharga yang mencantumkan kata "saham" di dalamnya sebagai tanda bukti pemilihan sebagian dari modal perseroan (Manan, 2012).

Saham atau stocks adalah surat bukti atau tanda kepemilikan bagian modal pada suatu perusahaan terbatas. Pemilik saham sekaligus juga merupakan pemilik perusahaan. Semakin besar saham yang dimiliki maka semakin pula kekuasaannya terhadap perusahaan tersebut. Keuntungan yang diperoleh dari perusahaan tersebut dinamakan dividen (Soemitra, 2009). Wujud saham adalah selembar kertas yang menerangkan bahwa pemilik kertas tersebut adalah pemilik perusahaan yang menerbitkan surat berharga (Rivai, 2014).

Saham syari'ah adalah sertifikat yang menunjukkan bukti kepemilikan suatu perusahaan yang diterbitkan oleh emiten yang kegiatan usaha maupun cara pengelolaannya tidak bertentangan dengan prinsip syari'ah. Saham merupakan surat berharga yang merepresentasikan penyertaan modal ke dalam suatu perusahaan. Sementara dalam prinsip syari'ah, penyertaan modal dilakukan pada perusahaan-perusahaan yang tidak melanggar prinsip syari'ah, seperti perjudian, riba, serta memproduksi barang yang diharamkan. Penyertaan modal dalam bentuk saham tersebut dapat dilakukan berdasarkan akad musyarakah dan mudharabah. Akad musyarakah pada umumnya dilakukan pada perusahaan yang bersifat privat, sedangkan akad mudharabah umumnya dilakukan pada saham perusahaan publik (Soemitra, 2009). 
Saham syariah menurut Dewan Syariah Nasional didefinisikan sebagai suatu bukti kepemilikan atas suatu perusahaan yang memenuhi kriteria syariah dan tidak termasuk saham yang memiliki hak-hak istimewa (Yuliana, 2010).

\section{Mekanisme OperasionalisasiSaham Syari'ah di Indonesia dan Negara}

\section{Lain}

\section{Mekanisme Saham Syari’ah di Indonesia}

Prinsip-prinsip penyertaan modal secara syari'ah di Indonesia tidak diwujudkan dalam bentuk saham syari' ah ataupun non syari'ah, melainkan berupa pembentukan indeks saham yang memenuhi prinsip-prinsip syari'ah(Aziz, 2010).

Pasar modal syari'ah dalam konteks saham syari'ah pada dasarnya tidak boleh mengandung transaksi ribawi, transaksi gharar, dan juga tidak boleh bergerak pada sektor yang diharamkan oleh syari'ah. Pasar modal ini seharusnya bebas dari transaksi yang tidak beretika seperti manipulasi pasar, insider trading, dan short selling. Transaksi pembelian dan penjualan saham di pasar modal syari'ah tidak boleh dilakukan secara langsung dan dilarang dalam Islam. Hal tersebut dikarenakan pada penjualan saham di pasar modal konvensional, investor dapat membeli dan menjual saham secara langsung dengan menggunakan jasa broker atau pialang. Sehingga memungkinkan bagi para spekulan untuk mempermainkan harga. Hal ini mengakibatkan perubahan harga saham sudah ditentukan oleh kekuatan pasar, bukan karena nilai intrinsik saham itu sendiri lagi. Oleh karena itu, emiten memberikan otoritas kepada agen di lantai bursa pada proses perdagangan saham syari'ah. Lalu agen tersebut bertugas mempertemukan antara emiten dan calon investor namun bukan untuk menjual dan membeli saham secara langsung. Pada tahapan berikutnya, saham tersebut dijual atau dibeli karena sahamnya memang tersedia dan berdasarkan prinsip first come-first served (Umam, 2013).

Proses penawaran umum pada pasar modal terdiri dari proses emisi dan perdagangan di bursa efek. Pada proses emisi, Perusahaan mengajukan permohonan pendaftaran kepada Bapepam di Jakarta melalui penjamin emisi 
(underwriter), dengan melampirkan:anggaran dasar/ akte pendirian perusahaan, prospektus, laporan keuangan yang telah diaudit, perjanjian emisi efek, comfort letter, legal opinion, serta dokumen-dokumen lain yang dibuat dalam rangka emisi. Apabila menurut hasil evaluasi BAPEPAM perusahaan tersebut telah memenuhi persyaratan untuk go public maka proses terakhir yang harus dilakukan adalah pendapat akhir yang bersifat terbuka untuk umum. Selanjutnya adalah perdagangan di bursa efek, yakni pencatatan efek-efek dari perusahaan yang wajib dicatat di bursa efek untuk diperdagangkan. Transaksi dilakukan oleh perantara perdagangan efek. Mekanisme perdagangan disini terdiri dari pasar primer dan pasar sekunder. Pasar primer merupakan transaksi antara emiten dan investor sebelum saham-saham diperdagangkan di pasar sekunder. Harga saham merupakan harga pasti yang tidak bisa ditawar dan merupakan kesepakatan antara perusahaan penjamin emisi dan emiten.Ada beberapa tahap penawaran saham pada pasar perdana, yakni (Ghufron, 2005):

1. Pengumuman dan Pendistribusian Prospektus

2. Masa Penawaran

3. Masa Penjatahan

4. Masa Pengembalian Dana

5. Penyerahan Efek

6. Pencatatan Efek

Pada pasar sekunder, perdagangan terjadi ketika perdagangan saham sudah melewati masa penawaran umum di pasar perdana, dan saham-saham tersebut telah tercatat di bursa efek untuk diperdagangkan. Harga saham di pasar sekunder sangat ditentukan oleh teori permintaan dan penawaran serta kondisi perusahaan yang menerbitkan saham (emiten). Harga saham disini adalah harga jual saham dari satu investor kepada investor yang lainnya. Harga saham yang ditawarkan pada kedua pasar ini berbeda dan pada mayoritasnya harga saham di pasar sekunder lebih tinggi dibandingkan dengan pasar perdana. Oleh karena itu perdagangan saham di pasar sekunder lebih mendekati pada unsur spekulasi dengan risiko tinggi yang mengandung unsur gambling yang dilarang dalam Islam (Aziz, 2010). 
Perdagangan saham di pasar sekunder sangat dipengaruhi oleh unsur insider trading. Hal ini menyebabkan terjadinya kompetisi yang tidak sehat di kalangan investor. Sikap insider trading ini sama dengan yang dilakukan oleh orang-orang kota ketika melakukan transaksi dengan mendatangi langsung orangorang desa, yang di dalamnya terdapat unsur penipuan karena orang desa (produsen) belum mengetahui secara pasti harga komoditas yang sebenarnya(Aziz, 2010). Sedangkan mekanisme perdagangan saham di pasar perdana masih merupakan perdagangan biasa, yang selembar sahamnya diperdagangkan sesuai dengan kualitas yang masih wajar.

Berbeda dengan mekanisme perdagangan saham secara konvensional, mekanisme perdagangan saham syari'ah secara spesifik dipertemukan pada Jakarta Islamic Index (JII) dan penawarannya hanya pada pasar perdana. Hal ini dilakukan dengan tujuan agar tidak ada lagi unsur-unsur spekulasi dan sikap insider trading, sebagaimana yang terjadi pada pasar sekunder selama ini (Aziz, 2010).

(Soemitra, 2009) menyatakan bahwa Jakarta Islamic Index (JII) dimaksudkan untuk digunakan sebagai tolak ukur untuk mengukur kinerja suatu investasi pada saham yang berbasis syari'ah. Melalui JII tersebut diharapkan dapat meningkatkan kepercayaan investor untuk mengembangkan investasi dalam ekuiti secara syari'ah. Penerbitan saham syari'ah oleh emiten atau perusahaan publik yang menyatakan bahwa kegiatan usaha serta pengelolaannya dilakukan berdasarkan prinsip syari'ah di pasar modal. Emiten dan perusahaan publik tersebut wajib mengikuti ketentuan umum pengajuan pertanyaan pendaftaran atau pedoman mengenai bentuk dan isi pertanyaan pendaftaran perusahaan publik serta ketentuan tentang penawaran umum yang terkait lainnya yang diatur oleh Bapepam LK dan mengungkapkan informasi tambahan dalam prospektus bahwa kegiatan usaha serta cara pengelolaan usahanya berdasarkan prinsip-prinsip syari'ah di pasar modal. Secara umum, perusahaan yang akan menerbitkan efek syari'ah harus memenuhi ketentuan sebagai berikut: 
1. Memuat ketentuan bahwa kegiatan usaha serta cara pengelolaan usaha dilakukan berdasarkan prinsip-prinsip syari'ah di pasar modal di dalam anggaran dasarnya.

2. Semua jenis usaha, akad, aset yang dikelola, cara pengelolaan oleh emiten, produk dan jasanya tidak boleh bertentangan dengan prinsip-prinsip syari'ah.

3. Emiten dan perusahaan publik tersebut memiliki anggota direksi dan komisaris yang mengerti dan paham mengenai kegiatan-kegiatan yang bertentangan dan tidak bertentangan dengan prinsip syari'ah.

Proses penyaringan emiten di JII terdiri dari tiga tahapan seleksi, yakni seleksi syari'ah, seleksi kapitalisasi, dan seleksi nilai volume transaksi. Skemanya adalah sebagai berikut:

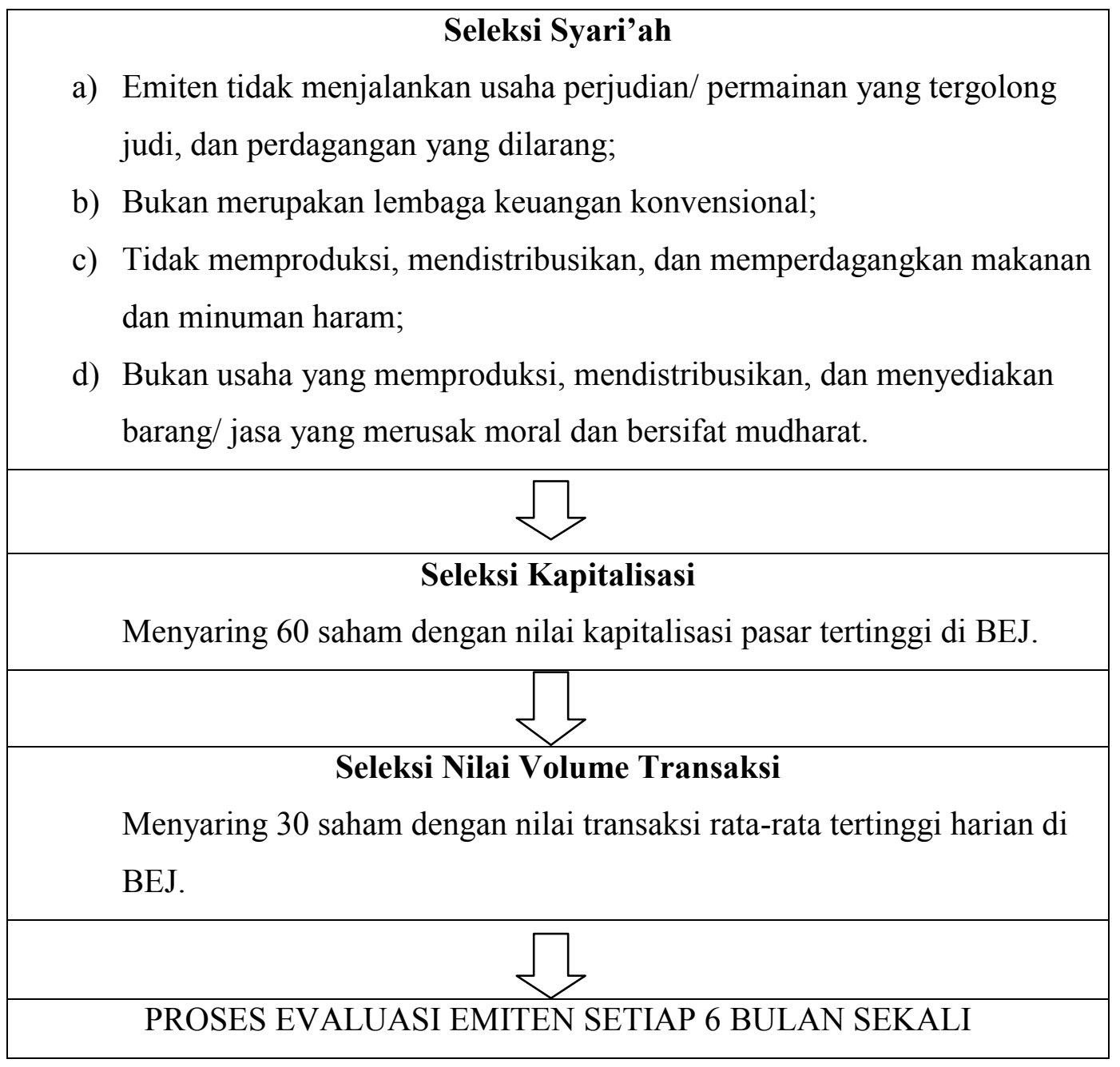


Komposisi keuangan perusahaan yang sahamnya tercatat di JII adalah tingkat likuiditasnya harus berada di rentang 17-49\%, dengan pendapatan bunga berada di kisaran antara 5-15\%, dan utang tidak boleh lebih dari 33\%. Dari sisi emiten, kondisi finansial dan manajemen menjadi ukuran layak tidaknya saham dicatat di JII. Berikut merupakan beberapa hal yang menjadi acuannya, yakni (Nasarudin, 2011):

1. Struktur utang (debt to equity ratio) tidak boleh didominasi oleh pembiayaan yang didasarkan pada sistem bunga. Perusahaan juga tidak boleh bergantung pada utang yang berbasiskan sistem konvensional.

2. Emiten tidak boleh mempunyai utang $45 \%$ dan modal $55 \%$. Jika hal ini terjadi maka emiten akan dinyatakan tidak layak mengundang investasi melalui pembelian sahamnya.

3. Emiten dinyatakan tidak layak jika manajemennya diketahui pernah melakukan tindakan yang bertentangan dengan prinsip syari'ah.

Pengelola JII akan melakukan pengkajian ulang setiap 6 bulan sekali dengan penentuan komponen indeks pada awal bulan Januari dan Juli setiap tahunnya. Perhitungan JII dilakukan oleh Bursa Efek Jakarta (BEJ) dengan menggunakan metode perhitungan indeks yang telah ditetapkan oleh BEJ, yakni dengan bobot kapitalisasi pasar (market cap weighted). Perhitungan indeks ini juga mencakup penyesuaian-penyesuaian (adjustment) akibat berubahnya data emiten yang disebabkan oleh corporate action. JII menggunakan tanggal awal perhitungan 1 Januari 1995 dengan nilai awal sebesar 100 (Nasarudin, 2011).

Berdasarkan peraturan BAPEPAM-LK, peraturan Nomor KEP314/BL/2007 Tentang Kriteria Penerbitan Daftar Efek Syari'ah yang dimuat dalam Peraturan II.K 1, yakni tidak melebihi rasio-rasio keuangan berikut:

a) Total hutang yang berbasis bunga dibandingkan dengan total ekuitas tidak lebih dari $82 \%$ (hutang yang berbasis bunga dibandingkan dengan total ekuitas tidak lebih dari 45\%:55\%); dan

b) Total pendapatan bunga dan pendapatan tidak halal lainnya dibandingkan dengan total pendapatan (revenue) tidak lebih dari 10\%. 


\section{Mekanisme Operasional Saham syari'ah di Malaysia}

Pada perkembangannya, Malaysia dan Amerika Serikat telah melakukan pembatasan terhadap suatu saham yang dapat dikategorikan sebagai saham syari'ah melalui Dow Jones Islamic Index. Sementara itu beberapa institusi keuangan dunia telah membuat juga batasan-batasan untuk kategori saham syari'ahnya melalui City Asset Management Group, Wellington Management Company, Islamic.com, dan lain sebagainya(Alma, 2009).

Pada saham syari'ah dikenal dengan istilah proses pemurnian (screening) pendapatan non halal. Proses pemurnian ini dilakukan hanya pada perusahaan yang halal namun diragukan pada pendapatan non halalnya. Metode yang digunakan adalah sebagai berikut(Ghufron, 2005):

\section{Metode I}

Total pendapatan 200 juta

Pendapatan non halal 20 juta

Cleasing factor $=10 \%$

Jika perusahaan mendapatkan capital gain Rp 5.000.000

Cleasing factor 10\% dari capital gain

Pendapatan halal

$\underline{\mathrm{Rp} \quad 500.000}+$ Rp 5.500.000

Jika pada dividen:

Dividen Rp 2.000.000

Cleasing factor $10 \%$

Dividen halal

\section{Metode II}

Pada metode ini, Cleasing factor dilakukan dengan menghitung pendapatan non halal yang diakui sebagai pendapatan. Sedangkan pendapatan non halal tidak dapat diakui sebagai pendapatan. Metode yang digunakan adalah sebagai berikut(Ghufron, 2005):

Total income

Rp 200.000.000

Rp 200.000.000 
Pendapatan non halal

Pendapatan kotor

Total biaya

Laba yang diakui

Total laba
Rp 20.000.000

Rp 180.000 .000

Rp 100.000.000

Rp 80.000 .000

Rp 100.000.000

cleasing factor $=\frac{\text { Total laba }- \text { Laba yang diakui }}{\text { Total laba }}$

$=\frac{100-80}{100} \times 100 \%$

$=20 \%$
Jika: Capital gain

$=\operatorname{Rp} 5.000 .000$

Cleasing factor $(20 \%)$

Capital gain halal

$=\underline{\operatorname{Rp~} 1.000 .000}$

$=\operatorname{Rp} 4.000 .000$

Jika : Dividen

$=\operatorname{Rp} 2.000 .000$

Cleasing factor $(20 \%)$

Dividen halal
$=\underline{\operatorname{Rp} \quad 400.000}$

$=\operatorname{Rp} 1.600 .000$
Rp 200.000.000

Rp 100.000.000

\section{1) DJGI (Dow Jones Global Index)}

Dow Jones Islamic Market Index (DJIMI) adalah bagian dari kelompok indeks-indeks global Dow Jones (DJGI) yang meliputi saham-saham dari 34 negara dan mencakup 10 sektor ekonomi, 18 sektor pasar, 51 kelompok, dan 89 subkelompok industri berdasarkan standar klasifikasi Dow Jones Global. DJIMI tidak memasukkan indeks keseluruhan kelompok industri mana pun yang menggambarkan ketidakcocokan dengan garis bisnis berdasarkan prinsip-prinsip Islam. Kegiatan yang dilarang tersebut, seperti: jasa keuangan konvensional (perbankan, pegadaian, dan sebagainya), rokok, ternak babi, perjudian, industri hotel dan hiburan, minuman beralkohol, dan lain sebagainya yang dilarang oleh syari'at. Selain screening terhadap nilai-nilai Islam tersebut DJIMI juga melakukan screening kinerja keuangan dengan batasan-batasan seperti berikut(Heykal, 2010): 
a. Perbandingan antara utang dan modal atau debt to equity ratio (DER) tidak boleh melebihi $33 \%$.

b. Piutang perdagangan tidak boleh melebihi $45 \%$ dari total aset.

c. Non operating interest income/ operational income tidak melebihi $9 \%$.

\section{2) KLSI (Kuala Lumpur Syari'ah Index) dan RHBIMI (Rashid Husein Berhad Islamic Market Index)}

Menurut Haikal (2010) KLSI adalah indeks rata-rata tertimbang yang terdiri dari sekurutas-sekuritas yang tercatat pada Main Board Kuala Lumpur Composite Index (KLCI) yang telah melakukan penyaringan secara Islam sesuai dengan ketentuan yang ditetapkan oleh Badan Penasihat Islam dari Komisi Sekuritas Malaysia.KLSI diluncurkan pada 17 April 1999 untuk memenuhi tuntutan investor dalam dan luar negeri yang ingin berinvestasi di saham yang sesuai dengan hukum Islam. Saat ini telah terdapat 1025 saham yang terdaftar di bursa saham Malaysia, yang 75\% adalah saham Islam. RHBIMI adalah pasar modal Islam pertama di Malaysia yang diperkenalkan oleh Rashid Hussein Group Malaysia pada 1 Juni 1992. RHBIMI merupakan indeks yang berbasis kapitalisasi yang didasarkan pada perusahaan yang listing di Kuala Lumpur Stock Exchange Main Board dan Second Board. Setiap saham yang ingin masuk ke indeks saham maka harus lolos terlebih dahulu dari kriteria yang ditetapkan oleh RHBIMI ini. Kriteria saham yang tidak halal menurut RHBIMI dan akan dikeluarkan dari indeks saham terdiri dari kriteria kualitatif dan kuantitatif, sebagai berikut:

1. Kriteria Kualitatif

- Perusahaan yang operasionalnya berdasarkan riba, seperti bank institusi keuangan konvensional;

- Perusahaan yang operasionalnya melibatkan perjudian;

- Perusahaan yang aktivitasnya melibatkan pabrikasi dan atau penjualan produk yang haram seperti alkohol, makanan haram, dan daging babi.

- Operasi perusahaan mengandung elemen ketidakpastian, seperti bisnis asuransi konvensional.

- Aktivitas inti perusahaan mengandung empat kriteria diatas dan bertentangan dengan prinsip Islam; 
- Image perusahaan tidak baik di mata publik;

- dan aktivitas inti perusahaan tidak memiliki keuntungan bagi umat dan bangsa.

\section{Kriteria Kuantitatif}

SAC (Shariah Advisory Council/ Dewan Penasihat Syari'ah) di Malaysia menetapkan beberapa pembanding yang didasarkan pada ijtihad untuk menentukan toleransi percampuran antara saham yang diperbolehkan dan tidak diperbolehkan terhadap pendapatan dan keuntungan sebelum pajak sebuah perusahaan. Jika pendapatan dari usaha yang tidak diperbolehkan syari'ah melebihi batasan yang telah ditetapkan maka saham perusahaan tersebut tidak dikategorikan sebagai saham syari'ah. Batasan-batasan yang ditetapkan tersebut adalah sebagai berikut (Hanafi, 2011):

a. Batasan 5\%

Batasan ini dipergunakan untuk berbagai aktivitas bisnis yang secara tegas dilarang oleh syari'ah, seperti bunga (riba, dari lembaga keuangan konvensional seperti bank, perjudian, dan aktivitas minuman keras, serta babi).

b. Batasan $10 \%$

Batasan ini dipergunakan untuk berbagai aktivitas bisnis yang dilarang tetapi sangat sulit dihindari, seperti bunga simpanan deposito perbankan konvensional dan produk rokok.

c. Batasan $20 \%$

Batasan ini dipergunakan terhadap penerimaan sewa dari aktivitas bisnis yang tidak diperkenankan oleh syari'ah seperti penerimaan dari perjudian, minuman keras, dan lain sebagainya.

d. Batasan 25\%

Batasan ini dipergunakan untuk aktivitas bisnis yang diperbolehkan oleh syari'ah dan memiliki kemaslahatan tetapi masih terdapat unsur yang dapat mempengaruhi kesyari'ahan aktivitas tersebut, seperti: hotel, 
perdagangan saham, broker saham, dan aktivitas bisnis yang bertentangan dengan syari'ah.

\section{3) FTSE Global Islamic Index Series (FTSE GIIS)}

FTSE bekerjasama dengan investor internasional dan meluncurkan FTSE GIIS pada akhir Desember 1998. GIIS merupakan indeks-indeks pencontohan saham yang dirancang untuk mencatat (track) kinerja dari perusahaan-perusahaan perdagangan publik terdepan yang aktivitas bisnisnya konsisten dengan prinsipprinsip Islam. GIIS dihitung pada setiap akhir hari kerja bersamaan dengan penghitungan indeks-indeks FTSE di seluruh dunia. Mata uang yang digunakan untuk GIIS adalah dolar Amerika Serikat.

GIIS adalah bagian dari seluruh kelompok indeks dunia dari FTSE yang melibatkan saham dari 29 negara. FTSE memiliki 15 indeks-indeks saham yang diklasifikasikan berdasarkan pada industri 10 indeks dan wilayah (global, Amerika Eropa, Pacific Basin, Afrika Selatan). Perusahaan yang dimasukkan dalam GIIS adalah perusahaan yang terdaftar sebagai anggota dari salah satu FTSE dan yang memenuhi prinsip syari'ah (Heykal, 2010).

\section{Perkembangan Saham Syariah di Indonesia dan Negara Lain}

Pengembang pertama indeks syari'ah dan equity fund adalah Amerika Serikat. Setelah The Amana Fund diluncurkan, lalu The North American Islamic Trust diluncurkan sebagai equity fund pertama di dunia pada tahun 1986. Tiga tahun kemudian, Dow Jones Index meluncurkan Down Jones Islamic Market Index (DJIM). Shariah Suvervisory Board (SSB) dari Dow Jones Islamic Market(DJIM) melakukan filterisasi terhadap saham-saham halal berdasarkan aktivitas bisnis dan rasio finansialnya (Huda, 2008).

Secara spesifik, SSB akan langsung mengeluarkan perusahaan yang memiliki usaha dalam bidang-bidang, seperti: alkohol, rokok, daging babi, jasa keuangan konvensional, pertahanan dan persenjataan, hotel, kasino/perjudian, cinema, dan musik. Selanjutnya saringan kedua berupa ketentuan atas rasio keuangan untuk mengeluarkan perusahaan-perusahaan dengan utang dan/atau tingkat pendapatan dari bunga. Perusahaan-perusahaan tersebut akan dikeluarkan dari DJIM jika (Huda, 2008): 
i. $\quad$ Total utang/total aset $=$ atau $>33 \%$

ii. Total piutang/total aset $=$ atau $>47 \%$

iii. Non operating interest income/operating income $=$ atau $>9 \%$

Saham yang terdaftar di pasar modal tidak semuanya memenuhi prinsip syari'ah. Oleh karena itu Bursa Efek bekerjasama dengan Danareksa Investment Management dengan mengembangkan suatu indeks untuk menyaring sahamsaham yang layak dianggap memenuhi prinsip-prinsip syari'ah. Indeks ini disebut juga dengan Jakarta Islamic Indeks (JII) (Rivai, 2014).

Saham yang dikategorikan mendekati prinsip syari'ah adalah saham perusahaan yang tidak terkait dengan aktivitas haram seperti riba, gharar, judi, pornografi, memproduksi serta memperjualbelikan minuman keras, rokok, dan lain sebagainya. Di Indonesia, saham-saham yang memenuhi prinsip syari'ah baik dari segi jenis maupun operasional usahanya tergabung dalam JII dan diperdagangkan di Bursa Efek. Investor yang memiliki kemampuan sendiri berinvestasi langsung ke instrumen saham dan dapat memilih saham di dalam daftar JII tersebut.

Saham-saham yang memenuhi kriteria indeks saham syari'ah adalah emiten yang kegiatan usahanya tidak bertentangan dengan syari'ah seperti (Manan, 2012):

1. Usaha perjudian dan permainan yang tergolong judi atau perdagangan yang dilarang oleh syari'ah.

2. Usaha lembaga keuangan konvensional termasuk perbankan dan asuransi yang beroperasi secara konvensional.

3. Usaha yang memproduksi, mendistribusi serta memperdagangkan makanan dan minuman yang tergolong haram berdasarkan hukum Islam.

4. Usaha yang memproduksi, mendistribusi, atau menyediakan barangbarang ataupun jasa yang merusak moral dan bersifat merugikan.

Selain kriteria di atas, dalam proses pemilihan saham yang akan masuk ke JII, Bursa Efek Jakarta melakukan tahap-tahap pemilihan yang juga mempertimbangkan aspek likuiditas dan kondisi keuangan emiten, yaitu (Manan, 2012): 
1. Memilih kumpulan saham dengan jenis usaha utama yang tidak bertentangan dengan prinsip syari'ah dan sudah tercatat lebih dari 3 bulan.

2. Memilih saham berdasarkan laporan keuangan tahunan atau tengah tahun berakhir yang memiliki rasio kewajiban terhadap aktiva maksimal sebesar $90 \%$.

3. Memilih 60 saham dari susunan saham di atas berdasarkan urutan ratarata kapitalisasi pasar terbesar selama satu tahun terakhir.

4. Memilih 30 saham dengan urutan berdasarkan tingkat likuiditas ratarata nilai perdagangan reguler selama satu tahun terakhir.

Perkembangan pasar modal syari'ah di Indonesia khususnya pada saham syari'ah belum menggambarkan perkembangan yang cukup baik jika dibandingkan dengan perkembangannya di Malaysia. Walaupun JII sudah bekerja dengan cukup baik, Indonesia masih sangat jauh tertinggal dalam pengembangan kegiatan investasi syari'ah dipasar modal (Aziz, 2010).

Saat ini terdapat 1025 saham yang terdaftar di bursa saham di Malaysia, dan sekitar 70\% dianggap sesuai dengan syari'ah (Nasution, 2009). Dalam perkembangannya, pasar saham syari'ah di Malaysia terus mengalami peningkatan. Berdasarkan data dari KLSI, Malaysia telah mempunyai 1278 saham yang patuh syari'ah, 319 saham pada tahun 2000, 436 saham pada tahun 2003, 521 saham pada tahun 2006, 513 pada tahun 2007 dan 522 saham pada tahun 2008(Borhan, 2009). Malaysia mempunyai cara tersendiri dalam proses penyaringan saham syari'ah. Proses penyaringan adalah aturan-aturan untuk memastikan bahwa saham-saham ataupun sekurutitas lainnya telah mematuhi ketentuan syari'ah. Proses kepatuhan ini dibagi menjadi dua, yakni proses penyaringan dan pemurnian saham. Proses penyaringan dimulai dengan menyaring perusahaan-perusahaan dalam hal kegiatan-kegiatan, prooduk, dan industrinya. Selain itu, terdapat sekumpulan ukuran yang disebut filter keuangan yang digunakan oleh para cendikiawan muslim untuk meningkatkan pemilihan saham-saham dan filter-filter tersebut menggunakan sejumlah rasio keuangan dan 
patokan yang berhubungan untuk menyisihkan saham-saham yang tidak diperbolehkan, misalnya(Billah, 2010):

1. Aset likuiditas, yang berkisar antara $17-49 \%$;

2. Pendapatan bunga, rasio ini haruslah antara 5-15\%;

3. Rasio hutangnya harus antara 30-33\%.

Perusahaan akan digolongkan patuh syari'ah apabila telah memenuhi persyaratan tersebut. Kriteria lain yang harus dipenuhi oleh suatu perusahaan adalah perusahaan harus sejalan dengan hukum Islam, seperti dengan baiknya citra perusahaan, tujuan perusahaan adalah untuk kepentingan publik, dan unsur haram yang tidak besar. Penerapan proses penyaringan menurut komisi sekuritas Malaysia dan Indeks Islam Dow Jones (Billah, 2010)

1. Komisi sekuritas, Malaysia

Pada tahap I, kegiatan perusahaan yang terdiri dari: operasi berbasis pada riba, operasi melibatkan perjudian, membuat dan/atau menjual produk haram, operasi mengandung undur riba dan gharar, maka perusahaan akan ditolak.

Selanjutnya pada tahap 2, jika pada tahap pertama perusahaan tidak ditolak maka ada kriteria tambahan, yakni: unsur haram pada perusahaan sedikit dibandingkan dengan kegiatan inti, citra publik terhadap perusahaan baik, kegiatan inti perusahaan memiliki kepentingan dan diijinkan, maslahat bagi umat muslim atau negara, maka perusahaan akan diterima

\section{Indeks Islam Dow Jones}

Pada tahap I, seleksi dilakukan terhadap kegiatan, industri, dan produk perusahaan. Kriteria perusahaan yang ditolak antara lain: melakukan kegiatan yang tidak diijinkan, produksi daging babi, produk makanan non halal, minuman beralkohol, perjudian, lembaga keuangan berbasis bunga, hiburan/entertainment, tembakau, dan kegiatan lainnya yang bertentangan dengan Islam.

Jika pada tahap I perusahaan tidak melakukan kagiatan diatas maka ada tahap selanjutnya yakni tahap 2 yang melakukan saringan rasio keuangan. Perusahaan akan diterima jika:

- Total hutang terhadap rasio total aset lebih kecil dari atau $=33 \%$

- Piutang terhadap rasio total aset lebih kecil atau $=45 \%$ 
- Kas + sekuritas menghasilkan bunga selama 12 bulan.

- Kapitalisasi pasar rata-rata bergerak lebih kecil atau $=33 \%$.

Malaysia sudah sejak tahun 1990 mengembangkan kegiatan investasi syari'ah di pasar modal dan terus berkembang dengan pesat. Sedangkan Indonesia memulai hal yang sama pada pertengahan tahun 1997. Pada akhir tahun 2002 Malaysia telah memiliki 36 reksa dana syari'ah dari total 174 Reksa Dana yang ada di Malaysia dan total nilai aktiva bersih (NAB) tersebut mencapai 5\% dari total NAB reksa dananya. Sementara Indonesia baru memiliki 10 Reksa Dana syari'ah dari total 223 reksa dana yang ada di pasar modal pada awal November 2004 dengan NAB sebesar 0,32\% dari keseluruhan NAB reksa dana yang ada di Indonesia (Aziz, 2010).

Pengawasan terhadap mekanisme operasional saham syari'ah di Indonesia diawasi oleh OJK (Otoritas Jasa Keuangan). Sebelumnya, pengawasan tersebut merupakan tugas menteri keuangan, BAPEPAM, dan Bank Indonesia, namun setelah keluar Undang-Undang mengenai OJK maka pengawasan terhadap semua lembaga keuangan syari'ah di Indonesia dialihtugaskan kepada OJK.

Berdasarkan Undang-Undang Nomor 21 Tahun 2011, Otoritas Jasa Keuangan (OJK) adalah lembaga yang independen dan bebas dari campur tangan pihak lain, mempunyai fungsi, tugas, dan wewenang pengaturan, pengawasan, pemeriksaan, serta penyidikan terhadap Lembaga Jasa Keuangan, berupa: Perbankan, Pasar Modal, Perasuransian, Dana Pensiun, Lembaga Pembiayaan, dan Lembaga Jasa Keuangan Lainnya, dalam hal ini: pergadaian, lembaga penjaminan, lembaga pembiayaan ekspor Indonesia, perusahaan pembiayaan sekunder perumahan, dan lembaga yang menyelenggarakan pengelolaan dana masyarakat yang bersifat wajib, serta lembaga jasa keuangan lain yang dinyatakan diawasi oleh OJK berdasarkan peraturan perundang-undangan.

Latar belakang pembentukan OJK dikarenakan perlunya suatu lembaga pengawasan yang mampu berfungsi sebagai pengawas yang mempunyai otoritas terhadap seluruh lembaga keuangan, dimana lembaga pengawas tersebut bertanggung jawab terhadap kegiatan usaha yang dilakukan oleh bank maupun lembaga keuangan non bank, sehingga tidak ada lagi lempar tanggung jawab terhadap pengawasannya. Selain itu, kegiatan usaha yang dilakukan berakibat 
semakin besarnya pengaturan pengawasannya. Sehingga perlu adanya suatu alternatif untuk menjadikan pengaturan dan pengawasan maupun lembaga (Hermansyah, 2011).

\section{E. Permasalahan Mekanisme Operasional Saham Syari’ah}

Ada beberapa isu dan permasalahan pada saham syari'ah dan mekanisme operasionalnya. permasalahan ini terjadi karena pertentangan antara teori dan praktik pada saham syari'ah sendiri serta pertentangan dengan nilai dan prinsipprinsip syari'ah. Salah satu permasalahannya adalah saham syari'ah yang boleh masuk ke JII disyaratkan memiliki nilai ketidakhalalan (haram/riba) maksimal sebesar $15 \%$. Hal ini tentu bertentangan dengan prinsip-prinsip syari'ah karena Islam mengajarkan umat muslim untuk tidak memakan yang haram walaupun sedikit.

Sementara pada proses jual beli saham syari'ah, para pemain saham akan membeli saham jika harga saham sedang turun dan akan menjualnya pada saat harga naik. Hal ini bertentangan dengan nilai-nilai etika dalam Islam. Islam juga melarang untuk menikmati keuntungan diatas kerugian orang lain. Pada prinsipnya, saham itu nilainya adalah 1:1. Jika salah satu pihak mendapatkan keuntngan maka pihak lainnya akan mengalami kerugian. Begitu seterusnya, sehingga keberadaan saham syari'ah ini juga masih dalam perdebatan para ulama.

Pada saham syari'ah, sebagian investor sengaja melempar harga saham sehingga harganya menjadi jatuh karena terlalu banyak penawaran. Pemilik saham yang kecil kemudian segera menjual kembali saham dengan harga yang sangat murah karena khawatir harga saham tersebut akan semakin jatuh dan mereka semakin rugi. Pada akhirnya harga saham akan terus turun. Pada saat itu para investor besar akan berkesempatan untuk membelinya kembali dengan harga yang sangat murah dengan harapan akan bisa meninggikan kembali harga saham tersebut dengan banyaknya permintaan. Hal ini menyebabkan para investor besar tersebut mengalami keuntungan yang sangat besar dan para investor kecil lah yang menanggung kerugiannya dikarenakan perbuatan para investor besar yang berpura-pura melempar kertas saham (al-Mushlih, 2004).Perdebatan mengenai keberadaan efek syari'ah ini berdasarkan pada kekhawatiran bahwa pasar ini akan menyebabkan hilangnya modal besar-besaran dalam waktu singkat dan di sisi lain 
akan menyebabkan munculnya orang kaya baru yang tanpa mengeluarkan keringat. Hal ini akan menyebabkan terjadinya ketidakseimbangan pasar dalam perekonomian.

Di pasar modal, larangan syari'ah diatas mesti diimplementasikan dalam bentuk aturan main yang mencegah praktek spekulasi, riba, gharar, dan maysir. Salah satunya adalah dengan menetapkan minimum holding period atau jangka waktu memegang saham minimum. Dengan aturan ini, saham tidak bisa diperjualbelikan setiap saat, sehingga meredam motivasi mencari untung dari pergerakan harga saham semata. Pembatasan ini memang meredam spekulasi tetapi juga membuat investasi di pasar modal menjadi tidak liquid. Padahal tidak mungkin seorang investor yang rasional betul-betul membutuhkan likuiditas mendadak sehingga harus mencairkan sahamnya yang dipegangnya, sedangkan ia terhalang belum lewat masa minimum holding period-nya. Metwally mengusulkan minimum holding period setidaknya satu pekan. Selain itu, Ia juga memandang perlu adanya celling price berdasarkan nilai pasar perusahaan. Lebih lanjut Akram Khan melengkapi, untuk mencegah spekulasi di pasar modal maka jual beli saham harus diikuti dengan serah terima bukti kepemilikan saham yang diperjualbelikan (Huda, 2008).

Mengenai keberadaan pasar sekunder, pada hakikatnya saham syari'ah tidak memiliki pasar sekunder karena dikhawatirkan akan berdampak pada spekulasi. Namun dalam praktiknya, saham syari'ah tetap menggunakan pasar sekunder sebagai instrumennya.

Permasalahan lainnya mengenai mekanisme operasional saham syari'ah di Indonesia, yaknipada artikel yang ditulis oleh Mamduh H. Hanafi dan Syafiq Mahmadah Hanafi, dalam jurnal Ekonomi dan Bisnis Islam pada Tahun 2012, berdasarkan hasil penelitian mereka menunjukkan bahwa tidak ada perbedaan antara penyaringan saham syari'ah dan saham konvensional di Indonesia. Saham syari'ah diwakili oleh JII dan saham konvensional oleh LQ45(Hanafi M. M., 2012). Hal ini menjadi permasalah yang penting karena jika tidak ada perbedaan yang signifikan antara keduanya maka pada hakikatnya investor muslim juga sudah terjerumus dalam konsep riba, gharar, dan maysir yang dilarang oleh syari'at. 
Perbedaan mengenai penetapan kriteria kesyari'ahan perusahaan di suatu negara sebenarnya juga menjadi permasalahan. Di Indonesia, JII menetapkan kriteria kesyari'ahannya dengantingkat likuiditasnya harus berada di rentang 17$49 \%$, dengan pendapatan bunga berada di kisaran antara 5-15\%, dan utang perusahaan tidak boleh lebih dari 33\%. Berbeda dengan DJIM, suatu perusahaan akan dikeluarkan dari DJIM jika total utang/total aset = atau lebih besar dari 33\%; total piutang/total aset $=$ atau lebih besar dari 47\%; dan Non operating interest incomeloperating income $=$ atau lebih besar dari 9\%. Sementara KLSI berbeda lagi dalam penetapan kriteria kesyari'ahan saham syari'ahnya yang mempunyai beberapa batasan, dengan rentang 5\%, 10\%, 20\%, dan 25\% (Bakar, 2012).

Perbedaan tersebut tentu dikarenakan perbedaan wilayah dan pemahaman dari ulamanya, sehingga perbedaan mengenai pemahaman agama pun sangat terlihat. Berbeda ulama maka berbeda pula mazhab dan pemahaman agamanya. Mazhab yang dianut pada suatu negara juga mempengaruhi kriteria kesyari'ahan sehingga ada negara yang terlalu ketat dalam hal kriteria syari'ah dan ada pula yang terlalu bebas dan longgar, sehingga belum adanya satu aturan dan standar baku yang seragam bagi seluruh negara yang menerapkan prinsip pasar modal syari'ah, walaupun telah ada standar dari DJIM namun dalam praktiknya, masingmasing negara akan memberlakukan kriteria sendiri dalam praktik dalam negerinya.

\section{F. Kesimpulan}

Saham syari'ah merupakan salah satu instrumen dalam pasar modal syari'ah yang dijalankan berdasarkan prinsip-prinsip syari'ah. Mekanisme operasional dari saham syari'ah terdiri dari proses emisi dan perdagangan di bursa efek. Perdagangan di bursa efek ini terdiri dari perdagangan di pasar primer dan pasar sekunder. Pada pasar primer, harga saham bersifat pasti. Berbeda dengan pasar sekunder yang harga sahamnya bersifat fluktuatif berdasarkan demand dan suply serta perusahaan yang menerbitkan saham sendiri. Keberadaan pasar sekunder ini telah menimbulkan perdebatan antara ulama dan ekonom muslim. Pasar sekunder dianggap berdampak menimbulkan tindakan kecurangan dan 
spekulatif. Namun dalam praktiknya pasar sekunder di saham syari'ah tetap dibutuhkan

Penilaian kriteria saham syari'ah secara garis besar terbagi menjadi dua, yakni kriteria kualitatif dan kriteria kuantitatif. Kriteria kualitatif didasarkan pada halal dan haramnya aktivitas bisnis sebuah perusahaan. Sementara kriteria kuantitatif didasarkan pada kinerja keuangan perusahaannya. Terdapat perbedaan pada penetapan kriteria kesyari'ahan keuangan tersebutdi beberapa negara, khususnya pada JII, DJIM, dan KLSI.

Pada JII, tingkat likuiditasnya harus berada di rentang 17-49\%, dengan pendapatan bunga berada di kisaran antara 5-15\%, dan utang tidak boleh lebih dari 33\%.Pada DJIM, sebuah perusahaan akan dikeluarkan dari DJIM jika total utang/total aset sama dengan atau lebih besar dari 33\%; total piutang/total aset sama dengan atau lebih besar dari 47\%; dan Non operating interest income/operating income sama dengan atau lebih besar dari 9\%. Sementara KLSI berbeda lagi dalam penetapan kriteria kesyari'ahan saham syari'ahnya karena terdiri dari batasan-batasan tertentu.

\section{DAFTAR PUSTAKA}

Adam, Noor Latiffah, dan Nordin Abu Bakar, "Shariah Screening Process in Malaysia", INHAC: International Halal Conference, PWTC, Kuala Lumpur, 2012.

Al-Mushlih, Abdullah, dkk, Fikih Ekonomi Keuangan Islam, Penj. Abu Umar Basyir, Jakarta: Darul Haq, 2004.

Alma, Buchari, dkk, Manajemen Bisnis Syariah, Bandung: Alfabeta, 2009.

Aziz, Abdul, Manajemen Invetasi Syari'ah, Bandung: Alfabeta, 2010.

Billah, Mohd Ma'sum, Penerapan Pasar Modal Islam, Terj. Yusuf Hidayat, dkk, Jakarta: Universitas Al Azhar Indonesia, 2010.

Fatwa DSN-MUI Nomor 80/DSN-MUI/III/2011, Tentang Penerapan Prinsip Syariah dalam Mekanisme Perdagangan Efek Bersifat Ekuitas di pasar Reguler Bursa Efek. 
Fatwa DSN-MUI Nomor 40/DSN-MUI/X/2003, Tentang Pasar Modal dan Pedoman Umum Penerapan Prinsip Syari'ah di Bidang Pasar Modal.

Ghufron, Sofiniyah, Terj. Muhammad Firdaus, dkk, Sistem Kerja Pasar Modal Syariah, Jakarta: Renaisan, 2005.

Hanafi, Mamduh M., Syafiq M. Hanafi, "Perbandingan Kinerja Investasi Syariah dan Konvensional: Studi Pada Jakarta Islamic Index (JII) dan Indeks LQ45”, Jurnal EKBISI (Vol. VII, No. 1, Desember 2012, Hal. 16-27), Yogyakarta: Jurnal Ekonomi dan Bisnis Islam, 2012.

Hanafi, Syafiq Mahmadah, "Perbandingan Kriteria Syari'ah Pada Indeks Saham Syari'ah Indonesia, Malaysia, dan Dow Jones", Asy-Syir'ah: Jurnal Ilmu Syari'ah dan Hukum (Vol. 45, No. 11, Juli-Desember 2011), Yogyakarta: Fakultas Syari'ah dan Hukum UIN Sunan Kalijaga, 2011.

Hermansyah, Edisi Revisi, Hukum Perbankan Nasional Indonesia, Jakarta: Kencana, 2011.

Huda, Nurul, dan Mohammad Heykal, Lembaga Keuangan Islam: Tinjauan Teoritis dan Praktis, Jakarta: Kencana, 2010.

Huda, Nurul, dan Mustafa Edwin Nasution, Current Issues Lembaga Keuangan Syari'ah, Jakarta: Kencana, 2009.

Jakarta: Kencana, 2008.

, Investasi Pada Pasar Modal Syariah,

Hussin, Mohd. Yahya Mohd., dan Joni Tamkin Borhan, "Analisis Perkembangan Pasaran Saham Islam di Malaysia”, Jurnal Syari'ah (Vol. 17, No. 3, 2009, 431-456).

Manan, Abdul,Aspek Hukum dalam Penyelenggaraan Investasi di Pasar Modal Syariah Indonesia, Ed. 1, Cet. 2, Jakarta: Kencana, 2012.

, Hukum Ekonomi Syariah: Dalam Perspektif Kewenangan Peradilan Agama, Jakarta: Kencana, 2012.

Nasarudin, M. Irsan, Aspek Hukum Pasar Modal Indonesia, Ed. 1, Cet. 7, Jakarta: Kencana, 2011.

Peraturan BAPEPAM-LK Nomor KEP-314/BL/2007 Tentang Kriteria dan Penerbitan Daftar Efek Syari'ah.

Peraturan Otoritas Jasa Keuangan Nomor/POJK.04/2014 Tentang Penerbitan Saham Syariah. 
Rahman, Azhar Abdul, Mohd Azlan Yahya, dan Mohd Herry Mohd Nasir, "Islamic Norms for Stock Screening: A Comparison between The Kuala Lumpur Stock Exchange Islamic Index and The Dow Jones Islamic Market Index," International Journal of Islamic and Middle Eastern Finance Management, Vol. 3 lss 3 pp. 228-240, 2010.

Rivai, Veithzal, dkk, Islamic Economics: Ekonomi Syariah Bukan Opsi, tetapi Solusi!, Jakarta: Bumi Aksara, 2009.

Rivai, Veithzal, dkk, Principle of Islamic Finance (Dasar-Dasar Keuangan Islam): Saatnya Hijrah ke Sistem Keuangan Islam yang Telah Teruji Keampuhannya, Cet. 2, Yogyakarta: BPFE, 2014.

Soemitra, Andi, Bank dan Lembaga Keuangan Syariah, Jakarta: Kencana, 2009.

Umam, Khaerul, Pasar Modal Syari'ah dan Praktik Pasar Modal Syariah, Bandung: CV. Pustaka Setia, 2013.

Undang-Undang Republik Indonesia Nomor 21 Tahun 2011 Tentang Otoritas Jasa Keuangan

Yuliana, Indah, Investasi Produk Keuangan Syariah, Malang: UIN Maliki Malang Press, 2010. 